\title{
MAGNETIC ANALYSIS OF ABAETÉ DIAMONDIFEROUS DISTRICT (MINAS GERAIS, BRAZIL) AND ITS POSSIBLE PRIMARY SOURCES
}

\author{
Gisella Magalhães Silva, Issamu Endo and Maria Sílvia Carvalho Barbosa
}

\begin{abstract}
This work studies the origin of the diamonds from the important mining region, Abaeté Diamondiferous District (Minas Gerais, Brazil). The discovery of pipes with micro diamonds and/or crater facies kimberlites in the entire Alto Paranaíba Igneous Province (macro region of Abaeté District) enhanced the interest about understanding the diamonds origins. The diamonds from this district usually show few cleavages, present more than 100 carats (ct) and are associated to numerous indicator minerals for kimberlite, suggesting proximity between their primary and current sources. In order to corroborate with the area geophysics knowledge, high resolution maps were prepared using airborne magnetic data integrated with geology and field studies. The products were used to: suggest the continental fracture zones which allowed the ascent of alkaline magma; correlate magnetic responses with stratigraphic and tectonic features; indicate the magnetic responses of the lineaments that govern the diamantiferous drainages; suggest possible kimberlite clan rocks; and estimate the basement depth by Euler Deconvolution. The crystalline basement is concave and the sedimentary rocks thickness may achieve about $3,000 \mathrm{~m}$. The magnetic anomalies selected as possible kimberlite clan rocks were detailed using ground magnetic surveys and their Analytic Signal was adopted to estimate the magnetic source geometries by Euler Deconvolution. These possible kimberlitic pipes look like each other and presenting depths of up to $200 \mathrm{~m}$ and diameters of up to $300 \mathrm{~m}$.
\end{abstract}

Keywords: mineral prospecting, Euler Deconvolution, Alto Paranaíba lgneous Province.

RESUMO. Este trabalho estuda a origem dos diamantes de uma importante região mineradora, o Distrito Diamantífero Abaeté (MG). A descoberta de kimberlitos com microdiamantes e/ou fácies de cratera em toda Província Ígnea do Alto Paranaíba (macrorregião do distrito) aumentou o interesse de compreender a origem destes diamantes. Os diamantes da área geralmente apresentam poucas feições de clivagem, mais que 100 quilates (ct) e estão associados aos minerais indicadores de rochas kimberlíticas, sugerindo proximidade entre suas fontes primárias e atuais. A fim de contribuir com o conhecimento geofísico da área, mapas geofísicos de alta resolução foram confeccionados usando dados aeromagnéticos integrados à geologia e aos estudos de campo da região. Os produtos desta integração foram utilizados para: sugerir as zonas de fraturas continentais que permitiram a ascensão magmática alcalina; correlacionar a magnetometria com a estratigrafia e as feições tectônicas; indicar as feições magnéticas dos lineamentos que regem as drenagens diamantíferas; sugerir possíveis rochas do clan kimberlítico; e estimar a profundidade do embasamento através da Deconvolução de Euler. 0 embasamento cristalino é côncavo e a espessura das camadas de rochas sedimentares atinge cerca $3.000 \mathrm{~m}$. As anomalias magnéticas, selecionadas como possíveis intrusões kimberlíticas, foram detalhadas em levantamentos magnéticos terrestres e a Deconvolução de Euler foi aplicada em dados de Sinal Analítico destes levantamentos. As possíveis intrusões kimberlíticas são semelhantes entre si, apresentando não mais que $200 \mathrm{~m}$ de profundidade e $300 \mathrm{~m}$ de diâmetro.

Palavras-chave: prospecção mineral, Deconvolução de Euler, Província Ígnea do Alto Paranaíba.

Universidade Federal de Ouro Preto, Department of Geology, School of Mines, Campus UFOP, 35400-000 Ouro Preto, MG, Brazil. Phone: +55(31) 3559-1600 E-mails: gmagalhaess@gmail.com; issamu.endo@gmail.com; mscbarbosa@gmail.com 


\section{INTRODUCTION}

Worldwide, kimberlites and lamproites are important diamond sources (e.g. Pereira, 2007; Chaves et al., 2008). Usually the high magnetic susceptibility from pipes produces significant contrast with the surrounding rock, and they may be mapped using the magnetic method. It is believed that magnetometry has much to contribute to the knowledge of Brazilian kimberlite provinces (e.g. Pereira, 2007).

The current geophysical study selected an extremely interesting gemological region and at the same time does not differ from the geological setting of the Brazilian diamondiferous regions that contain well-known kimberlitic rocks. The region chosen was Abaeté Diamondiferous District, in the midwest of Minas Gerais State. Its geologic setting suggests proximity between primary sources and current sedimentary deposits (Pereira, 2007). This conjecture is due to important factors. Firstly numerous kimberlite pipes of commercial and scientific interest were found close to the district (Barbosa, 1991; Gonzaga \& Tompkins, 1991; Costa et al., 1997; Thomaz, 2009). In this geological scenario, the Canastra01 (in São Roque de Minas city) (Chaves et al., 2008) and X270 (near to Patos de Minas city) (Read et al., 2004) kimberlites are highlighted. The first was considered exploitable while the former presented crater facies kimberlitic, showing that not all kimberlite clan were completely eroded. Diamonds with few cleavages, gems larger than $100 \mathrm{ct}$, and the presence of abundant mineral indicators for kimberlite (including garnet, Cr-diopside, Mg-ilmenite and chromite and olivine) are usual in the Abaeté Diamondiferous District. In addition, the lithosphere presents a favorable environment for crystallization of diamonds which favor the existence of undiscovered diamondiferous intrusions (Pereira \& Fuck, 2005; Pereira, 2007).

\section{GEOLOGICAL CONTEXT}

The Abaeté Diamondiferous District is located on the east of the southwestern border of the Sanfranciscana Basin (Alkmim \& Martins-Neto, 2001; Alkmim, 2004) (Fig. 1). The district consists of three visible groups: Bambuí, Areado and Mata da Corda (Sgarbi et al., 2001). The Bambuí Group is constituted of pelites and carbonates passing to conglomerates and sandstones at the borders and at the top (Alkmim, 2004). The associations of siliciclastic and biochemical lithofacies were deposited in an extensive epicontinental sea during the Neoproterozoic (Iglesias \& Uhlein, 2009). The Cretaceous Areado Group is subdivided into three Formations: Abaeté, Quiricó and Três Barras designating basal conglomerates, lacustrine pelites and sandstones, respec- tively. The Mata da Corda Group is composed by the Patos and the Capacete Formations. The first consists of complexes of alkaline volcanic rocks and the second is composed by pyroclastic rocks, lavas and intrusive rocks reworked from the Patos Formation, also during the Cretaceous (Sgarbi et al., 2001). The Areado Group sits in erosive and angular discordance over the Neoproterozoic rocks. During the Cretaceous, the basaltic flows of the Paraná Basin and the opening of the South Atlantic Ocean modified the crustal balance and by isostatic compensation, the uplift of Alto Paranaíba Arc. Fracture zones where kimberlite clans intruded are associated with uplift of this arc. It is believed that the kimberlites ascended in a fast geological event between Lower and Upper Cretaceous (Read et al., 2004), dating predominantly from 89-120 Ma (Sgarbi et al., 2001).

\section{METHODOLOGY}

The airborne magnetic data sets used were provided by Companhia de Desenvolvimento de Minas Gerais (CODEMIG) and are part of Minas Gerais State Aerogeophysics Survey Program 2005/2006. The Abaeté Diamondiferous District is included in Area 7 (Patos de Minas-Araxá-Divinópolis) and also in Area 9 (João Pinheiro-Presidente Olegário-Tiros) (Lasa, 2007a,b). They surveys include N-S production lines separated by $0.4 \mathrm{~km}$ and $\mathrm{E}$ $W$ control lines distant from $8.0 \mathrm{~km}$ from each other. The average flight height was around $100 \mathrm{~m}$, and the instrument cesium vapor magnetometer with $0.01 \mathrm{nT}$ nominal precision was used. The intervals between the geophysical measurements were $0.05 \mathrm{~s}$ and $0.10 \mathrm{~s}$ and the magnetic datums were $23386 \mathrm{nT}$ (at 02/14/2007) and $23368 \mathrm{nT}$ (at 06/23/2006), respectively, Area 7 and Area 9 (for more details see Lasa, 2007a,b).

The reprocessing of the airborne surveys was initiated by leveling (and micro-leveling) the datasets to a common base. Afterwards, a set of maps including Anomalous Magnetic Field Map, First and Second Vertical Derivative Maps, and Analytical Signal Map were generated and analyzed. Geology and field studies (as search wells and collect of the indicator minerals for kimberlite) were incorporated into the analysis. As a result, some magnetic anomalies were chosen and detailed with ground magnetic surveys.

All magnetic detail surveys had lines oriented in N-S direction spaced of $100 \mathrm{~m}$. Along these lines the samples were collected at $10 \mathrm{~m}$ intervals. Samples for the diurnal variation correction were collected each $1 \mathrm{~h}$ and there were resampling daily of 2 stations to support the validation of ground databases. The solar radiation intensity was monitored daily by the site 

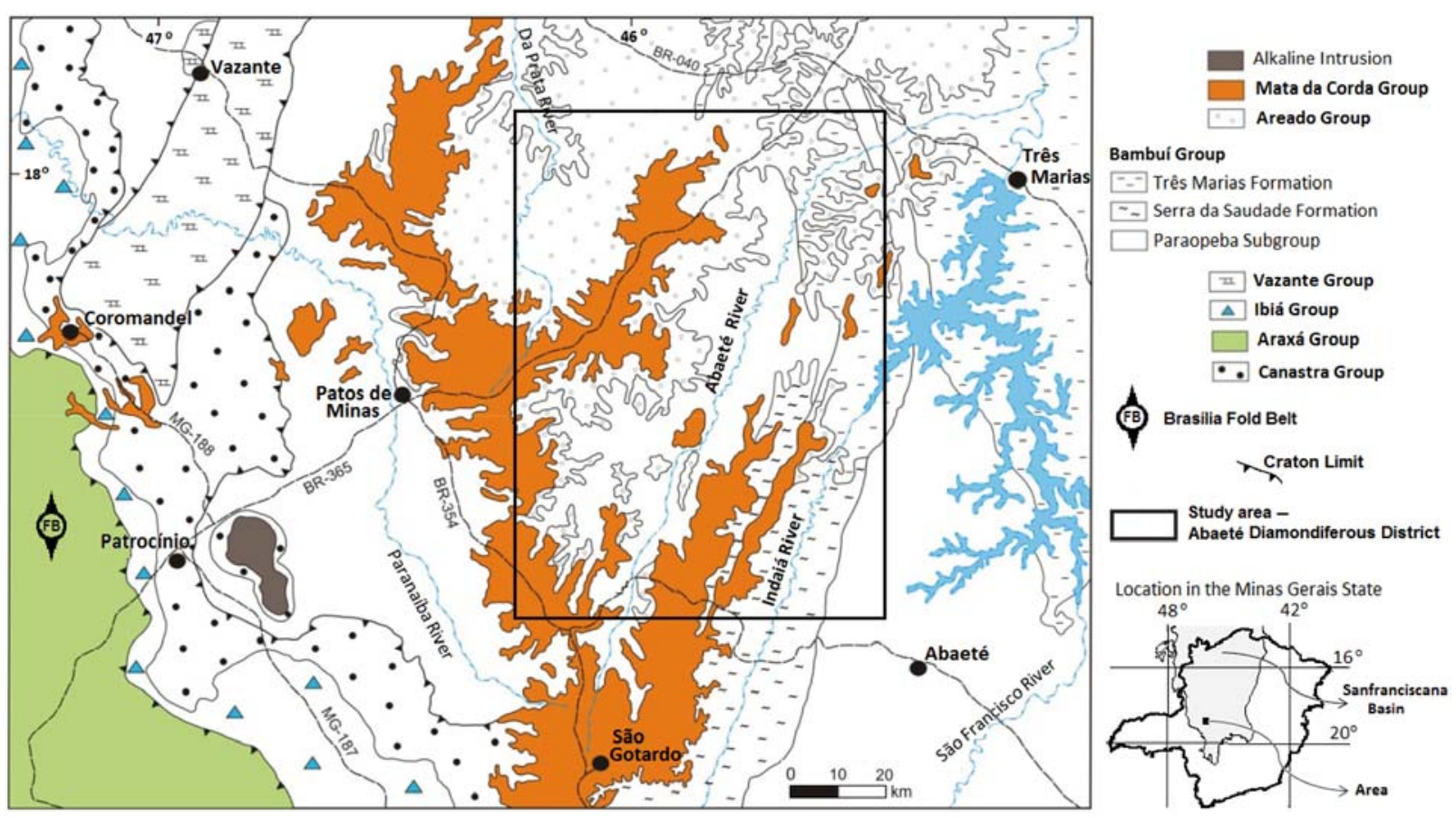

Figure 1 - The study area, Abaeté Diamondiferous District (Minas Gerais, Brazil), is located on the east of the Brasilia Fold Belt, Sanfranciscana Basin (adapted from Heineck et al., 2003).

http://www.ngdc.noaa.gov. Even with the previous knowledge of the behavior of Earth's magnetic field the records were analyzed, processed and validated at the end of each workday. The ground magnetic surveys were processed leveling all data, subtracting the IGRF and diurnal variation. The same set maps of the airborne databases was generated.

The inversion of magnetic data was made using the Analytical Signal. It is an efficient technique to determination of geometrical parameters, such as boundaries between magnetic and non-magnetic rocks by Euler Deconvolution. The Euler Deconvolution also infers the depth of source from the surface position and geophysical anomaly (Durrheim \& Cooper, 1998). It was adopted structural index equal to 1 for planar structures, estimated depth for display the responses of the $3500 \mathrm{~m}$ inversion and the window size 11 (dimensionless unit - for more details see Durrheim \& Cooper, 1998). Each profile infers the magnetic source depth as a cut (one slice) and the interpolation of many bidirectional profiles integrated to geological data, enable the understanding of the magnetic source geometries (for more details see Madeira et al., 2015).

The parameters adopted to generate the two-dimensional profiles to estimate the magnetic source depth was started with the creation of $\mathrm{E}-\mathrm{W}$ profiles (perpendicular to magnetic data). The spacing between them was one kilometer for the airborne surveys and $20 \mathrm{~m}$ for the ground surveys.

\section{RESULTS AND DISCUSSION}

The first results presented were the reprocessed magnetic maps using airborne surveys. Initially, the area was divided into two distinct domains based on its frequency content: a high frequency domain related to shallow sources and a low frequency domain related to deeper sources (Figs. 2 and 3).

First Vertical Derivative Map was selected for the graphical representation of the main magnetic anomalies and diamond drainages (Fig. 3). High frequencies responses are overlapped on very low frequency responses suggesting a large interval between them. It can be interpreted as the existence of a magnetized substrate, a large package of non-magnetic rocks and as well as magnetic rocks very close to the surface. The correlation to the airborne magnetic data and the regional geology (Sgarbi et al., 2001; Heineck et al., 2003; Read et al., 2004) suggest that high frequency anomalies arise from the mafic alkaline and ultramafic rocks of the Cretaceous Mata da Corda Group. Since the Areado and Bambuí groups do not contribute to the magnetic response, the low frequency anomalies should belong to structures of the crystalline basement (magnetic background). 

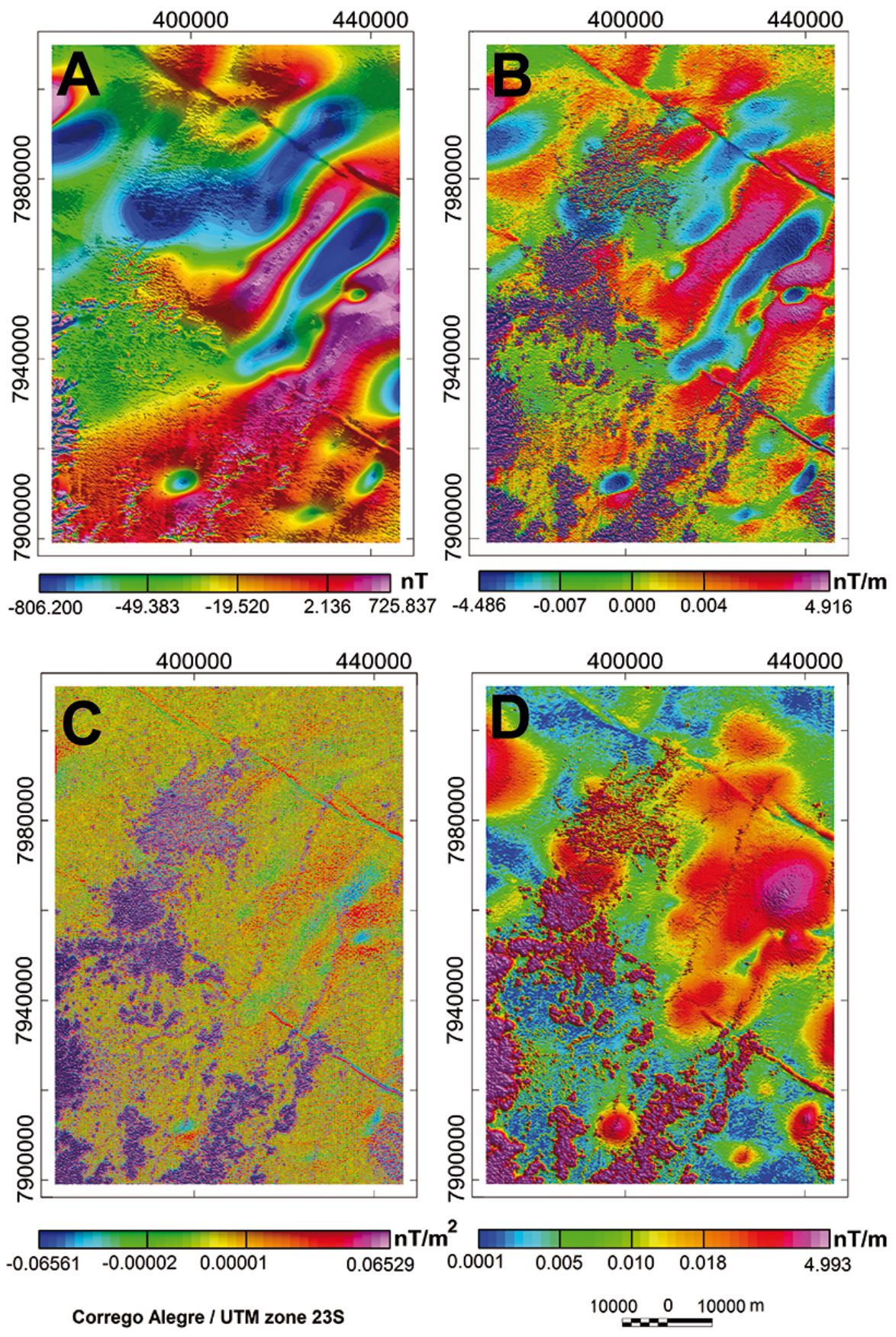

Figure 2 - (A) Anomalous Magnetic Field Map; (B) First Vertical Derivative Map; (C) Second Vertical Derivative Map and (D) Analytical Signal Map.

The NW-SE liners (Fig. 3) are the mega structural lineaments named 125 $5^{\text {th }}$ AZ (Gonzaga \& Tompkins, 1991; Hasui \& HaraIyi, 1991). The main feature of the NE-SW lineaments inside the Abaeté Diamondiferous District is its intrinsic relation to the structural control of the diamond drainages. Pereira (2007) calls attention to the importance of these linear structures in the prospection in (and around) diamondiferous kimberlites in the São Francisco Craton.

Euler results are presented as crosses (+) in two-dimensional profiles and account for the roof depth of magnetic source (Fig. 4). 

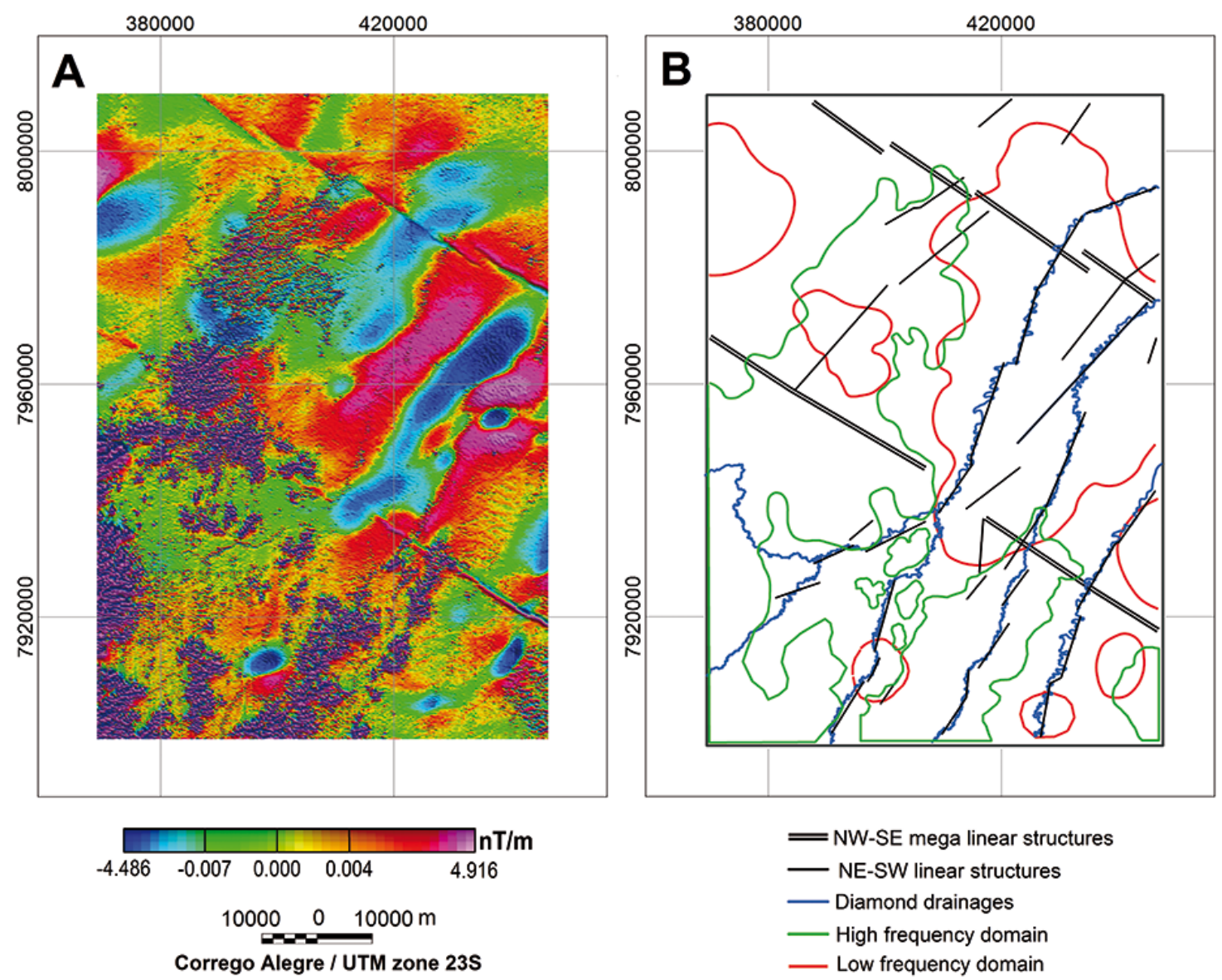

Figure 3 - (A) First Vertical Derivative Map and (B) graphical representation of the main magnetic anomalies and diamond drainages.

If only the magnetic maps were analyzed, it would be possible to imagine that the high magnetic values, in the low frequency domain, arise from some geologic high structural. However, the results of two-dimensional deconvolution profiles suggest the sedimentary rocks thickness may achieve $3000 \mathrm{~m}$ (Fig. 5). These results agree with those from the seismic and the borehole studied by Romeiro-Silva \& Zalán (2005) and high magnetic susceptibility could be generated by mineralogical variations of the basement São Francisco Craton. Who proposed that the basement of Sub-Basin Abaeté can be deeper than 3,000 m. In addition, they also suggested that the western boundary São Francisco Craton in subsurface is further west (under of Brasilia Fold Belt). Due to this, Pereira (2007) proposed that the NW-SE linear structural features (Fig. 3) break up areas where the Archean basement was preserved in midwest of Minas Gerais State.

According to Pereira (2007) the district has high potential for diamond-bearing kimberlites. Agreeing with his proposition, some magnetic responses integrated with the geology and studies field were selected as possible primary sources and their located are shown in the Analytical Signal Map (Fig. 6). These areas were detailed by the ground magnetometer surveys and their Analytic Signal was adopted to estimate the possible magnetic source geometries as airborne survey. The results of two-dimensional deconvolution profiles of the magnetic source number 1 (Fig. 6) is shown in the Figure 7.

Euler Deconvolution responses suggest that the magnetic responses selected as possible kimberlitic clan intrusions are similar. They are near surface, presenting depths of up to $200 \mathrm{~m}$ and diameters of up to $300 \mathrm{~m}$ (Fig. 7).

\section{CONCLUSIONS}

Airborne magnetic data was used to comprehend that nowadays, the main diamond drainages of the district are seated on NE-SW lineaments. However, in the past, the rivers could have been on other NE-SW lineaments too. This is useful information in order to propose mining areas far from current drainages. Euler Deconvo- 


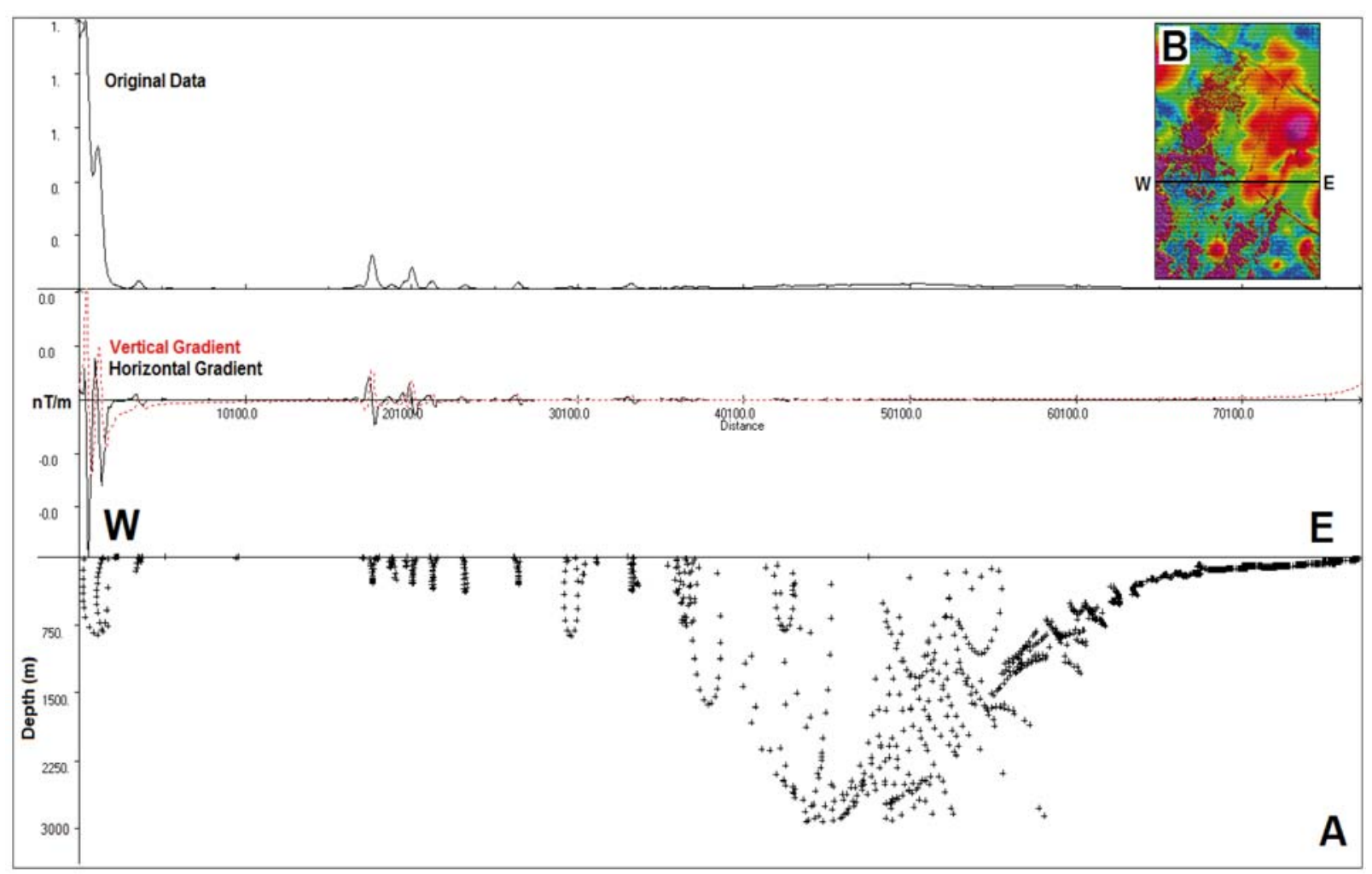

Figure 4 - (A) Estimated depth profile of the magnetic sources by Euler Deconvolution and (B) Analytical Signal Map with the location of the profile.

lution responses confirm that the district is divided into two magnetics domains: shallow sources related to Mata da Corda Group, as well as possible kimberlitic clan rocks and deeper sources related to basement. It is suggested that the basement would be concave and presenting depths of up to 3,000 m. Understanding how the Craton basement is really important to figure out the geological setting during the raise of the kimberlitic clan. Especially when comprehending in which areas these igneous rocks were able to bring gems. Fortunately, the Abaeté Diamondiferous District (Minas Gerais) exhibits favorable conditions for it. Ground magnetic surveys were integrated with geology and studies field (including search wells and collect of the indicator minerals for kimberlite) to build up this theory. Although the magnetic source geometries being similar each other presenting depths of up to $200 \mathrm{~m}$ and diameters of up to $300 \mathrm{~m}$, other sorts of pipes can be find out into the district. These possible primary sources are near $125^{\text {th }}$ AZ lineaments and many indicator minerals for kimberlites as garnet, diopside, and olivine are easily find. They are inside a mining area where there are giant gems (over than $100 \mathrm{ct}$ ) and diamonds displaying few transport are recurrently discovered. These evidences corroborate with the theory that Abaeté Diamondiferous District (MG) can be diamond-bearing kimberlites, including in commercial scale.

\section{ACKNOWLEDGEMENTS}

The authors thank Companhia de Desenvolvimento Econômico de Minas Gerais (CODEMIG) for the permition of use of the airborne magnetic data; company GAR Mineração Comércio e Exportação Ltda. for allowing the access to their research reports and for the collaboration of its researchers; Conselho Nacional de Desenvolvimento Científico e Tecnológico (CNPq), Coordenação de Aperfeiçoamento de Pessoal de Nível Superior (Capes) and Programa de Pós-Graduação em Evolução Crustal e Recursos Naturais, Universidade Federal de Ouro Preto, for funding and infrastructure.

\section{REFERENCES}

ALKMIM FF. 2004. 0 que faz de um cráton um cráton? 0 Cráton do São Francisco e as Revelações Almeidianas ao Delimitá-lo. In: MANTESSONETO V, BARTORELLI A, CARNEIRO CDR \& BRITO NEVES BB (Org.). Geologia do Continente Sul-Americano: Evolução da Obra de Fernando Flávio Marques Almeida. São Paulo, Brazil, Beca, p. 17-35.

ALKMIM FF \& MARTINS-NETO MA. 2001. A Bacia Intracratônica do São Francisco: Arcabouço estrutural e cenários evolutivos. In: PINTO CP \& MARTINS-NETO MA (Eds.). Bacia do São Francisco: Geologia e Recursos Naturais. SBG/MG, p. 9-30. 


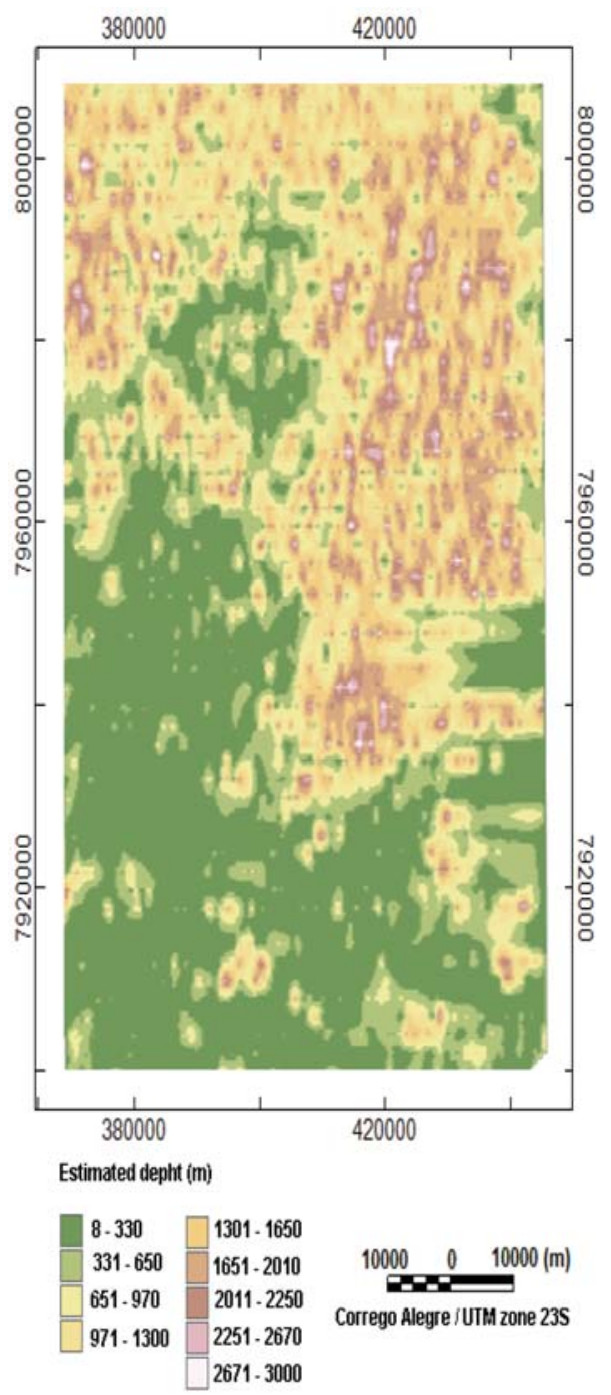

Figure $\mathbf{5}$ - Spatial positioning of the Euler solutions presenting the geologic compartmentation of the area.

BARBOSA 0. 1991. Diamante no Brasil: histórico, ocorrência, prospecção e lavra. Brasília, Brazil, CPRM. 136 pp.

CHAVES MLSC, ANDRADE KW, BENITEZ L \& BRANDÃO PRG. 2008. Província Diamantífera da Serra da Canastra e o kimberlito Canastra-1: Primeira fonte primária de diamantes economicamente viável do país. UNESP, Geociências, 27(3): 299-317.

COSTA VS, FIGUEIREDO BR \& WESKA RK. 1997. Estudos mineralógicos e químicos do kimberlito Batovi 6 (MT) em comparação com as intrusões Três Ranchos 4 (G0) e Limeira 1 (MG). Rev. Geochimica Brasiliensis, 11(1): 53-71.

DURRHEIM RJ \& COOPER GRJ. 1998. EULDEP: A program for the Euler Deconvolution of magnetic and gravity data. Elsevier - Computer \& Geosciences, 24(6): 545-550.
GONZAGA GM \& TOMPKINS LA. 1991. Geologia do Diamante. In: SCHOBBENHAUS C, QUEIROZ ET \& COELHO CE (Eds.). Principais Depósitos Minerais do Brasil, Gemas e Rochas Ornamentais. DNPM/CPRM. Volume IV, Parte A.

HASUI Y \& HARALYI NLE. 1991. Aspectos lito-estruturais e geofísicos do soerguimento do Alto Paranaíba. Bol. Geoc., 10: 57-77.

HEINECK CA, LEITE CAS, SILVA MA \& VIERA VS. 2003. Mapa Geológico do Estado de Minas Gerais, 1:1.000.000. Belo Horizonte, Brazil, Convênio COMIG/CPRM.

IGLESIAS M \& UHLEIN A. 2009. Estratigrafia do Grupo Bambuí e coberturas fanerozóicas no vale do rio São Francisco, norte de Minas Gerais. Rev. Bras. Geoc., 39(2): 256-266. 


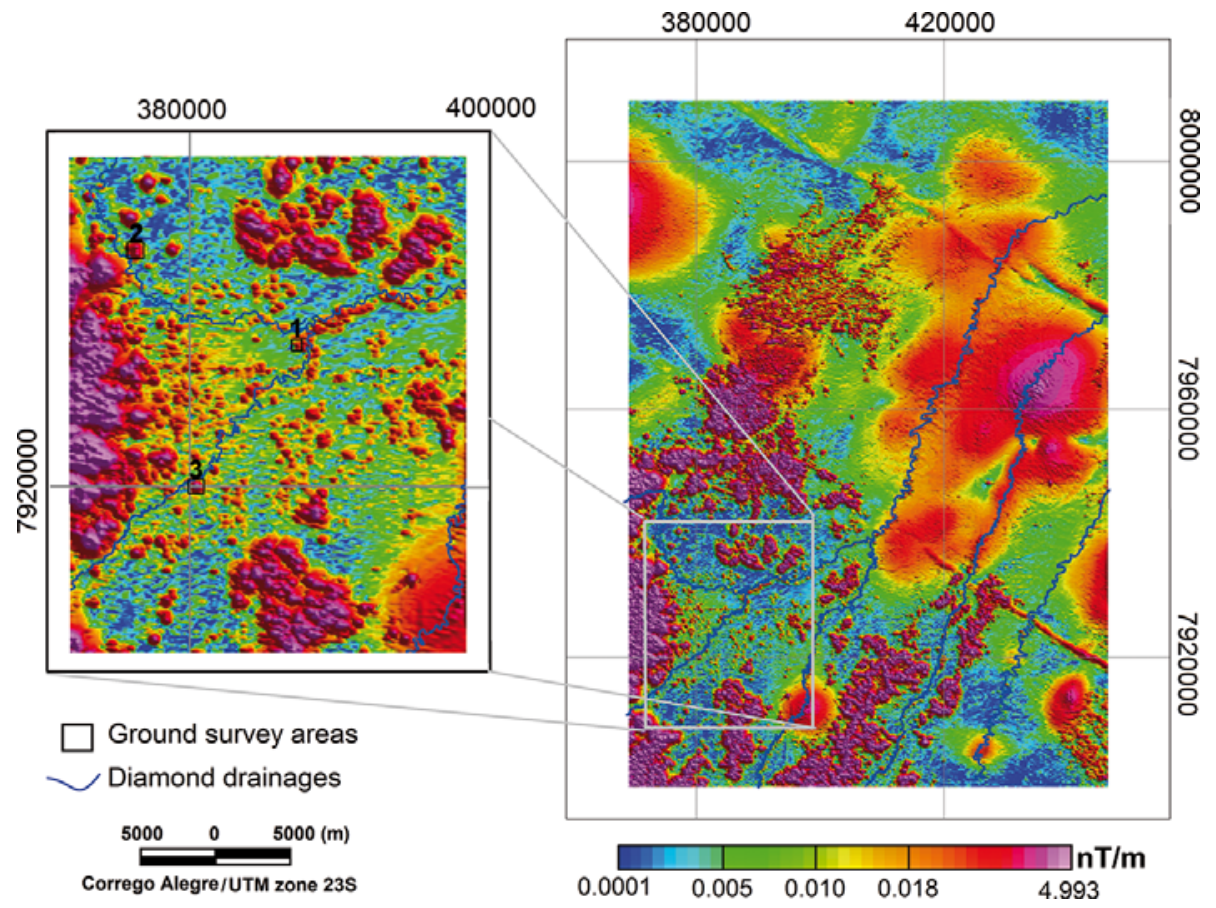

Figure 6 - Ground survey areas selected as possible kimberlitic clan rocks.

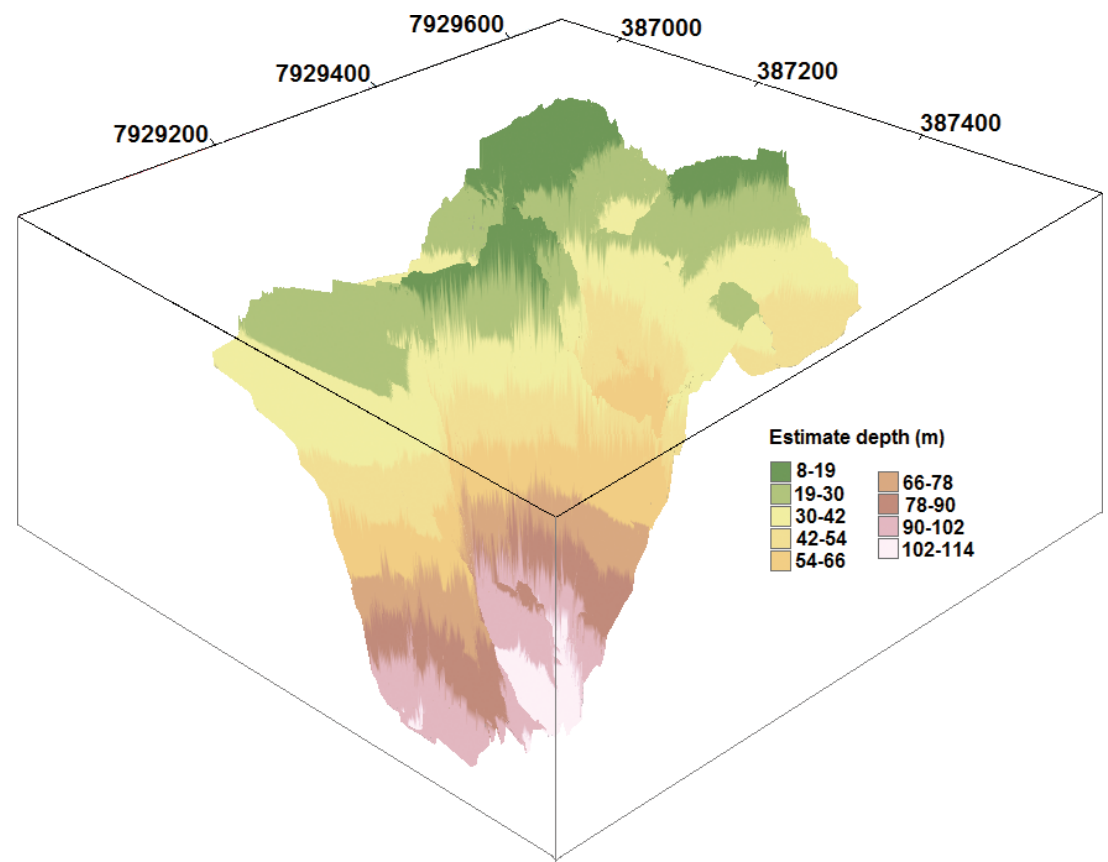

Figure 7 - Result of two-dimensional deconvolution profiles presenting one possible kimberlitic clan intrusion (ground survey number 1).

LASA ENGENHARIA E PROSPECÇÕES S.A. 2007a. Relatório Final do Levantamento e Processamento dos Dados Magnetométricos e Gamaespectrométricos. Área 7 - Patos de Minas-Araxá-Divinópolis. Levantamento Aerogeofísico de Minas Gerais. Secretaria de Estado de Desenvolvimento Econômico de Minas Gerais (SEDE), Brazil. 224 pp.
LASA ENGENHARIA E PROSPECÇÕES S.A. 2007b. Relatório Final do Levantamento e Processamento dos Dados Magnetométricos e Gamaespectrométricos. Área 9 - João Pinheiro-Presidente Olegário-Tiros. Levantamento Aerogeofísico de Minas Gerais. Secretaria de Estado de Desenvolvimento Econômico de Minas Gerais (SEDE), Brazil. 121 pp. 
MADEIRA TJA, BARBOSA MSC \& BORGES AJ. 2015. Interpretation of magnetic data based on Euler Deconvolution: Analysis of the main host gold structure in the northeastern portion of the Quadrilátero Ferrífero, MG, Brazil. Brazilian Journal of Geophysics, 33(3): 431-444.

PEREIRA RS. 2007. Cráton do São Francisco, kimberlitos e diamantes. Doctorate Thesis on Geophysics - Instituto de Geociências, Universidade de Brasília, Brazil, 200 pp.

PEREIRA RS \& FUCK RA. 2005. Archean Nucleii and the distribution of kimberlite and related rocks in São Francisco Craton, Brazil. Rev. Bras. Geoc., 35(3): 93-104.

READ G, GRUTTER H, WINTER S, LUCKMAN N, GAUNT F \& THOMSEN F. 2004. Stratigraphic relations, kimberlite emplacementand lithospheric thermal evolution, Quirico Basin, Minas Gerais State, Brazil. Lithos, 77:
803-818.

ROMEIRO-SILVA PC \& ZALÁN PV 2005. Contribuição da sísmica de reflexão na determinação do limite oeste do Cráton do São Francisco. In: Simpósio Cráton do São Francisco, 3., 2005, Salvador, Brazil. Proceedings, 44-47.

SGARBI GNC, SGARBI PB DE A, CAMPOS JEG, DARDENNE MA \& PENHA UC. 2001. Bacia Sanfranciscana: 0 registro Fanerozóico da Bacia do São Francisco. In: PINTO CP \& MARTINS-NETO MA (Eds.). Bacia do São Francisco: Geologia e Recursos Naturais. SBG/MG, p. 93-138.

THOMAZ LV. 2009. Estudo petrográfico e química mineral da intrusão kimberlítica Régis, no oeste de Minas Gerais. Master Dissertation on Geophysics - Instituto de Geociências, Universidade de São Paulo, Brazil, 2009. 143 pp.

Recebido em 23 setembro, 2014 / Aceito em 23 fevereiro, 2017

Received on September 23, 2014 / Accepted on February 23, 2017 